\title{
リパーゼ反応を利用した油脂加工 \\ Oil and Fat Processing by Lipase-Catalyzed Reactions
}

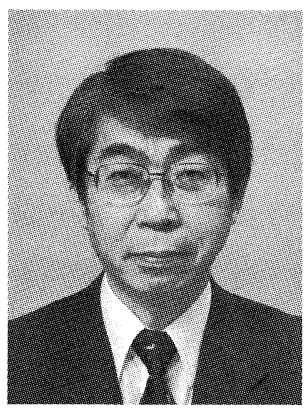

島田裕司

大阪市立工業研究所

T536-8553

大阪市城東区森之宮 1-6-50

Yuji SHIMADA

Osaka Municipal Technical

Research Institute

1-6-50 Morinomiya, Joto-ku,

Osaka 536-8553, JAPAN

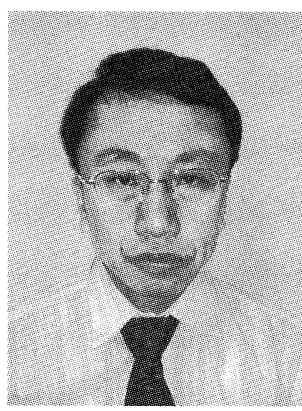

\section{永尾寿浩 \\ 大阪市立工業研究所 \\ †536-8553 \\ 大阪市城東区森之宮 1-6-50}

Toshihiro NAGAO

Osaka Municipal Technical

Research Institute

1-6-50 Morinomiya, Joto-ku,

Osaka 536-8553, JAPAN

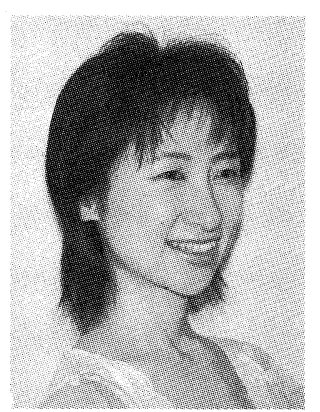

$$
\begin{gathered}
\text { 渡辺 嘉 } \\
\text { 大阪市立工業研究所 } \\
\text { † } 536-8553 \\
\text { 大阪市城東区森之宮 1-6-50 }
\end{gathered}
$$

Yomi WATANABE

Osaka Municipal Technical

Research Institute

1-6-50 Morinomiya, Joto-ku,

Osaka 536-8553, JAPAN

論文要旨：リパーゼは基質特異性（脂肪酸特異性，アルコール特異性，位置特異性など）を有し，加水分 解，エステル化，エステル交換反応を触媒する。この基質特異性と触媒する反応を組み合わせて構築したり パーゼ反応系は，化学反応では達成できない，あるいは達成しにくい油脂加工技術として利用できる。本稿 では，リパーゼ反応を利用した機能性油脂の製造，油糧資源から有用物質の精製，および未利用油糧資源の バイオディーゼル燃料への変換について述べる。

Abstract: Lipases have substrate specificities, such as fatty acid specificity, alcohol specificity, positional specificity and so on, and catalyze hydrolysis, esterification, and transesterification. Combination of the substrate specificity and catalyzed-reaction creates a valuable process for oil and fat processing, which can not be achieved by chemical processes. In this paper, production of functional oils and fats, purification of useful materials from natural oil resources, and conversion of unutilized oil resources to biodiesel fuel by lipase-catalyzed reactions are described.

Key words: lipase, substrate specificity, lipase-catalyzed reaction, functional oil and fat, polyunsaturated fatty acid, structure lipid, monoacylglycerol, tocopherol, sterol, biodiesel fuel

\section{1 はじめに}

1856 年，Bernard が㬸臓の破砕物中にトリアシルグリ セロール（TAG）を脂肪酸とグリセリンに分解する活 性があることを発見し，リパーゼの存在が確認された。 以来，リパーゼはアミラーゼ，プロテアーゼと並び三大 消化酵素と呼ばれている。しかし，基質が水に溶けない ため, 反応を解析する系の構築が難しく, 基礎および応

連絡者：島田裕司

E-mail : shimaday@omtri.city.osaka.jp
用研究はアミラーゼやプロテアーゼの研究に比べると著 しく遅れていた。このリパーゼに関する研究が活発化し たのは 1980 年代の中頃である。基礎研究では, Klibanov が 84 年に有機溶媒中での反応にリパーゼが利 用できることを示した。また，産業界ではリパーゼ反応 を利用したカカオ脂代替脂の生産が始まり, 洗剂用酵素 としてのリパーゼの利用も始まった。この頃は遺伝子操 作技術が飛躍的な発展を続けていたときでもあり，リ パーゼも遺伝子のクローン化, 一次構造の決定, 結晶構 造の解析の対象となっていた。この研究成果は 1990 年 
代に入って結実する。積年の疑問であったリパーゼの 油一水の界面活性化現象が, 酵素分子の活性中心を覆っ ている両親媒性のヘリックスの存在によって解決され た。また産業界では，91 年にエイコサペンタエン酸エ チルエステルが医薬品として認可され, 高度不飽和脂肪 酸が一躍注目されるようになり, 䤉素法による油脂加工 に拍車がかかる。この研究成果が, 酵素法による DHA 高含有油，母乳代替脂，ジアシルグリセロール，中鎖脂 肪酸含有油の製品化へと導いている。

このような時代の下にあって，リパーゼの油脂加工へ の利用が注目されたのはリパーゼの基質特異性と触媒す る多彩な反応である。本稿では, リパーゼの基質特異性 と反応をうまく組み合わせて確立された機能性油脂の製 造, 有用油脂関連化合物の精製, および未利用油糧資源 からのバイオディーゼル燃料生産について述べる。な お, ここで述べる油脂加工技術のうち, われわれが開発 した反応系の詳細は大阪市立工業研究報告（第 117 回と 第 129 回）にまとめてある ${ }^{1,2)}$ 。興味を扔持ちの方はこれ らの報告書も参照していただければ幸いである。

\section{2 機能性油脂の製造}

\section{$2 \cdot 1 \quad$ トリアシルグリセロール（TAG） \\ $2 \cdot 1 \cdot 1$ 高度不飽和脂肪酸 (PUFA) 高含有油}

一般にリパーゼは PUFA を認識しにくいという性質 を持ち，中でも Candida rugosa リパーゼはPUFAを 認識しにくい。そこで, 本酵素を用いてドコサへキサエ ン酸（DHA，22:6n-6）を含んだマグロ油を加水分解す ると，未分解アシルグリセロール画分の DHA 含量を 25 から $50 \%$ まで高めることができる ${ }^{3)}$ 。酵素反応後，DHA を高含有するアシルグリセロールは分子蒸留, あるいは ヘキサン分画により効率よく回収することができ, 得ら れたアシルグリセロールを原料として加水分解を繰り返 すと，さらに高濃度の DHA を含む油を製造することが できる。この選択的加水分解を $3 \sim 4$ 回繰り返すと DHA 含量を $70 \%$ まで高めることができる ${ }^{3)}$ 。

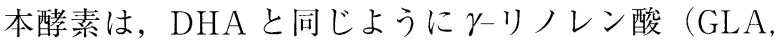
18:3n-6) やアラキドン酸（AA, 20:4n-6）も認識しに くいという特徴を持っている。したがって, 本酵素を用 いて GLA を含むボラージ油や AA を含む糸状菌油を加 水分解すると, 1 回の处理で $45 \% \mathrm{GLA}$ 含有油や，55\% AA 含有油を製造することもできる ${ }^{3)}$ 。

\section{$2 \cdot 1 \cdot 2$ 中鎖脂肪酸含有油}

大豆や菜種など多くの植物油は $\mathrm{C}_{18}$ の長鎖脂肪酸を主 成分とする TAG 分子種で構成されている。摂取された TAGは，すい臓リパーゼにより脂肪酸と2-モノアシル グリセロール（MAG）に分解されて腸粘膜から吸収さ
れる。吸収された分解物は TAGに再構成されて脂肪組 織に貯蔵された後，必要に応じて分解されてエネルギー 源となる。一方， $\mathrm{C}_{8}, \mathrm{C}_{10}$ の中鎖脂肪酸のエステル結合 は胃のリパーゼでも加水分解され，TAGに再構成され ることなく肝臓で分解されるため, 脂肪組織に蓄積され ない。この中鎖脂肪酸の特性が注目され，中鎖脂肪酸の $\mathrm{TAG}$ と長鎖脂肪酸の TAG をエステル交換した油が生 産されている。この油は, 特定保健用食品の認可を受け て 2003 年から発売されている。この種のエステル交換 油の製造にリパーゼを利用した反応が有効であるという 報告もある4)。

\section{$2 \cdot 1 \cdot 3$ 構造脂質}

天然油脂はグリセロール骨格の $2-$ 位に不飽和度の高 い脂肪酸が結合し，1,3-位に不飽和度の低い脂肪酸ある いは飽和脂肪酸が結合している傾向にある。しかし，結 合している脂肪酸の種類と結合位置は特定されておら ず，油脂を構成している $\mathrm{TAG}$ 種は多種多様である。一 方，グリセロール骨格に結合している脂肪酸とその結合 位置が特定されている TAG は構造脂質と呼ばれ，特徵 のある物性や保健機能を有することが知られている5)。

既に商品化されている構造脂質としてカカオ脂代替脂 (1,3-stearoyl-2-oleoyl glycerol, SOS; 1,3-behenoyl-2oleoyl glycerol, BOB) や, 母乳代替脂 (1,3-oleoyl-2palmitoyl glycerol, OPO) がある。SOS や BOB はカカ オ脂よりも高温側に，シャープな融点を持つという優れ た物性からチョコレートの融点調節用脂として使用され ている。また，OPO は乳児のエネルギー源として優れ た特性を持ち, Ca の吸収阻害を起こしにくいことから 育児粉乳の成分として使用されている。また，1,3-位に 中鎖脂肪酸が結合し，2-位に保健機能を持った長鎖脂肪 酸が結合した MLM 型構造脂質は，腸粘膜からの吸収性 に優れていることから高齢者向けのサプリメントとして の利用が期待されている。

これらの構造脂質は，基本的に天然油脂と脂肪酸（あ るいは脂肪酸エチルエステル）を原料とし，1,3-位特異 的リパーゼを触媒とした反応を行い，天然油脂の 1,3-位 の脂肪酸を目的脂肪酸でエステル交換することによって 製造することができる。この分野での研究は，まだ商品 化されていない MLM 型構造脂質の製造に集中し，目的 とする構造脂質を高収率，高純度に製造するために以下 のようなプロセスが提案されている5)。

\section{$2 \cdot 1 \cdot 3 \cdot 1$ 繰り返しエステル交換の利用}

固定化 1,3-位特異的リパーゼを触媒とし，天然油脂の 1,3-位の脂肪酸を中鎖脂肪酸（遊離体あるいはエチルエ ステル体）で交換する反応において，中鎖脂肪酸の量を 増やすとエステル交換率は上昇する。しかし，中鎖脂肪 
酸量を増やすほど処理できる原料油の量は減り，仕込み 原料に対する目的構造脂質の収率も低くなる。天然油脂 を収率よく高純度に MLM 型構造脂質に変換する際，中 鎖脂肪酸でエステル交換した後，アシルグリセロールを 回収し，回収アシルグリセロールを再度中鎖脂肪酸でエ ステル交換する繰り返し反応が効果的である。例えば, サフラワー油, アマニ油, AA 含有糸状菌油の 1,3-位の 脂肪酸を中鎖脂肪酸でエステル交換するとき，反応を 3 回繰り返すと，原料として用いた TAGをほぼ完全に MLM 型構造脂質に変換することができる ${ }^{6)}$ 。

\section{2・1・3・2 中間体として 2-MAG を製造する方法}

天然油脂の 1,3-位の脂肪酸のエステル交換には，1,3位特異的リパーゼが用いられている。現在報告されてい る 1,3-位特異的リパーゼは, 程度の差はあるが PUFA， とくにDHA や GLA に対する作用性が低い。また，マ グロ油やボラージ油は 1,3-位にも DHA や GLA が結合 している。したがって, 前項で述べた繰り返し反応を 行っても, マグロ油やボラージ油の 1,3-位の脂肪酸を全 て中鎖脂肪酸で交換することはできない。このようなリ パーゼが作用しにくい脂肪酸を含む油を MLM 型構造脂 質に変換するために，中間体として2-MAGを用いるプ ロセスが開発されている（Fig. 1)。
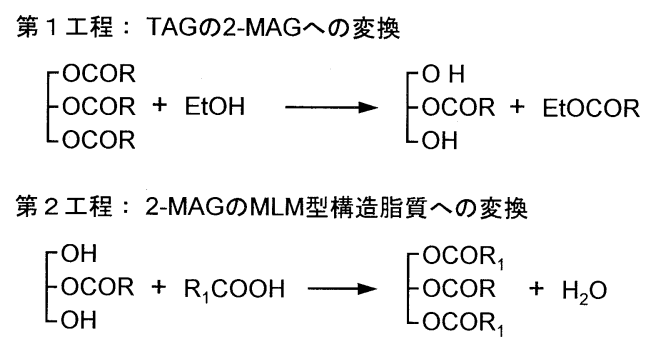

Fig. 1 2-MAG を中間体として用いる 2 段階反応による MLM 型構造脂質の製造

第 1 工程は，天然油脂の $2-\mathrm{MAG} へ$ の変換である。油 脂を 1,3-位特異的酵素で加水分解すると反応産物として 2-MAGを得ることができると考えられがちである。し かしこの加水分解の反応中にアシル基転移が進行するた め，2-MAG は反応系中に蓄積しない。一方, Irimescu ら゙)は, 過剩量のエタノール存在下で TAGをエタノリ シスすると, 顕著なアシル基転移が起こらないことを認 めた。また, PUFA もよく認識する固定化 Candida antarcticaリパーゼは, TAGの全構成脂肪酸量に対し て $1 / 2$ 量のエタノールでエタノリシスすると TAGのエ ステル結合の位置に対する特異性は示さない" ${ }^{8)}$ 。しかし， 過剩量（全脂肪酸に対して 20 モル以上）の EtOH でエ

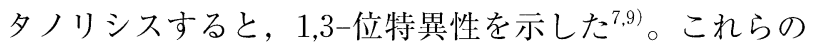
酵素的特徴を利用し，魚油をエタノリシスすることによ
り2-位にPUFA を多く含む $2-\mathrm{MAG}$ を調製することが できる。

第 2 工程は 2-MAG の MLM 型構造脂質への変換であ る。反応液中のエ夕ノールを減圧下で蒸発除去した後, 中鎖脂肪酸と固定化 $R$. miehei リパーゼを加えて反応さ せることにより2-位にPUFA を含有した高純度の MLM 型 TAG を合成することができた ${ }^{7,9)}$ 。

\section{$2 \cdot 1 \cdot 3 \cdot 3$ 天然油脂の選択的加水分解を含むプロセス}

高純度の MLM 型 TAG を合成するには単酸基 TAG を原料として用い，1,3-位の脂肪酸を中鎖脂肪酸に交換 しなければならない。天然油脂を原料としたときには， 1,3-位の脂肪酸を全て中鎖脂肪酸に交換できたとしても， 2-位に目的脂肪酸を持つ MLM 型 TAG の純度は天然油 脂の 2-位の目的脂肪酸含量より高めることはできない。 この課題は，2-位に目的脂肪酸を持たない TAGをあら かじめグリセリンと FFAに分解し，除去することに よって解決できる。すなわち，2·1·1 項で述べた方法， PUFA 含有油を C. rugosa リパーゼで選択的加水分解す ることにようて 2-位にPUFA を持たない TAGを脂肪 酸とグリセリンに分解することができる ${ }^{10,11)}$ 。反応後, 未分解のアシルグリセロールの 2-位の PUFA 含量は飛 躍的に上昇する。例えばボラージ油を選択的加水分解し てアシルグリセロールを回収すると2-位の GLA 含量は 49 から $85 \%$ まで高めることができるし ${ }^{10)}$, AA を含有 する糸状菌油を選択的加水分解すると 2 位の AA 含量を

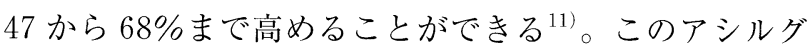
リ七ロールを $2 \cdot 1 \cdot 3 \cdot 1$ 項や $2 \cdot 1 \cdot 3 \cdot 2$ 項の方法で MLM 型 TAGに変換すると, 天然油脂を原料として用いても高 純度の目的構造脂質を製造することができる ${ }^{10,11)}$ 。

\section{$2 \cdot 2$ ジアシルグリセロール（DAG）}

$2 \cdot 1 \cdot 2$ 項で述べたように，食物として摂取された TAG は, 脂肪酸と $2-\mathrm{MAG}$ に分解されて小腸粘膜から 吸収される。吸収された分解物は TAGに再合成されて 一旦脂肪組織に蓄積された後, 必要に応じて分解されて エネルギー源となる。一方，摂取された 1,3-DAGは分 解・吸収された後に TAGに再合成されにくいため，体 脂肪がつきにくいといわれている。1,3-DAGは，基本的 に固定化 1,3-位特異的リパーゼを触媒として用い，グリ セリンに 2 モル量の脂肪酸を加えてエステル化すること により合成することができる。なお，エステル化反応に よって生じた水を減圧下で除去しながら反応を行うと， 1,3-DAG の純度および収率は向上する。酵素法によっ て生産された DAGは，1999 年に油脂関連製品で第 1 号 となる特定保健用食品の認可を受けている。

\section{$2 \cdot 3$ モノアシルグリセロール（MAG）}

食品用乳化剂として広く利用されている MAGは, 高 
温・高圧下で TAG をグリセロリシスすることにより製 造されている。この方法は飽和脂肪酸やモノエン酸の MAGの製造に適した方法であるが，二重結合を多く含 む不安定な脂肪酸の MAG の合成に適用することはでき ない。一方，温和な条件で反応が進行する酵素法は不安 定な脂肪酸の MAG 合成に適しており, TAGのグリセ ロリシス, TAGの加水分解, TAGのエタノリシス, グ リセリンと脂肪酸のエステル化などが提案されてい $3^{12)}$ 。

\section{3·1 TAG の加水分解/エタノリシス}

1,3-位特異的リパーゼを触媒として TAGを加水分解 すると理論的には $2-\mathrm{MAG}$ を作ることができる。しかし この反応中にアシル基転移が起こり，2-位の脂肪酸は 1,3-位に転移する。したがって，加水分解法を採用して MAG を効率よく製造する方法は確立されていない。

一方，2·1·3·2 項で述べたように, 固定化 C. antarctica リパーゼは過剩量の $\mathrm{EtOH}$ の存在下で 1,3-位特異性 を示し，この反応条件下でアシル基転移は非常に起こり にくい。したがって，本酵素を用い，TAGをエタノリ シスすると $2-\mathrm{MAG}$ を効率よく製造することができる が，原料として用いた TAGに対する $\mathrm{MAG}$ の収率は $30 \%$ 程度である ${ }^{7,13)}$ 。

\section{2·3·2 TAGのグリセロリシス}

$\mathrm{TAG}$ をグリセロリシスする反応系中には $\mathrm{TAG}$, DAG，MAG，グリセリン，およびFFA が存在する。 これらの化合物の中で MAGの融点が最も高い。また， リパーゼは液体状の基質にはよく作用するが，固体状の 基質には作用しにくい。したがって，MAGが固化する 温度で反応を行うと TAGを収率よく MAGに変換する ことができる ${ }^{14,15)}$ 。この反応の欠点として，反応時間が 長い（2 週間以上）こと，拈よび二重結合を 2 つ以上持 つ融点の低い脂肪酸の MAG を合成するには反応温度を 0 度以下に設定しなければならないことが指摘されてい $3^{16)}$ 。

\section{2·3·3 FFA とグリセリンのエステル化}

FFA とグリセリンをエステル化することにより FFA をアシルグリセロールに変換することができる。この反 応に打いて, Penicillium camembertii リパーゼ（MAG と DAG は認識するがTAGを認識しない）を触媒とし て用いると, 脂肪酸のエステル化率は $95 \%$ 以上に達し, MAG と DAG がほぼ等量合成される ${ }^{15.17) 。 ~}$

C. rugosa, Rhizopus oryzae, P. camembertii リパーゼ などを触媒とし，このエステル化を低温（MAG が固化 する温度）で行うと，2·3·2 項で述べたようにリパーゼ は MAGを基質として認識しないため $\mathrm{MAG} の \mathrm{DAG} へ$ の変換反応が進行せず MAG を収率よく合成することが
できる（エステル化率，95\%以上；MAGの収率，90\% 以上) ${ }^{18,19)}$ 。

\subsection{4 エステル化とグリセロリシスからなる 2 段階 in situ} 反応

前項（2·3·3 項）で述べたように, P. camembertiiり パーゼを用いて FFA とグリセリンを MAGが固化しな い条件下でエステル化すると，ほぼ等量の MAG と DAG が合成される。この反応液をそのまま $\mathrm{MAG}$ が固 化する低温で 2 週間以上放置しておくと，DAGがグリ セロリシスされてMAGに変換される。このエステル化 とグリセロリシスからなる 2 段階 in situ 反応を採用す ると FFA のエステル化率は $95 \%$ 以上に達し, MAGの 収率は $90 \%$ 以上となる ${ }^{15)}$ 。

\section{$2 \cdot 3 \cdot 5$ 脱水反応}

P. camembertii リパーゼを触媒とし, FFA とグリセ リンのエステル化を脱水しながら行う。初発水分量を 1 〜 $2 \%$ とし， $5 \mathrm{mmHg}$ の減圧下で脱水しながら反応を行 うと, 反応系中の水分量は $1,500 \mathrm{ppm}$ 程度に維持され, 48 時間反応でエステル化率は $95 \%$ 以上に達し, MAG 含 量は $90 \%$ 以上に達する ${ }^{20)}$ 。

この反応系は, 酵素の結合水量で説明できるかもしれ ない。2.3.3 項で述べたように脱水せずにエステル化反 応を行うと, 酵素は十分な（過剩量の）結合水を保持し ている。この状態にある酵素は MAGを基質として認識 し, MAGはDAGに変換され, 両産物がほぼ等量に なったときに反応は平衡に達する。一方, 脱水しながら 反応を行うと, 䤃素の結合水量は減少する。制限された 量の結合水しか持っていない酵素は $M A G$ を基質として 認識できなくなるため MAG から DAGへの変換反応は 進行しない。

\section{3 有用物質の精製}

䤃素は基質特異性を持ち, 多成分からなる反応系中で も特定の基質に対する反応だけを触媒するという特徵を 持つ。この酵素の特性を利用して, 原料中の夾雑物質を 他の分子型に変換する，あるいは目的化合物だけを他の 分子型に変換することができれば目的化合物の精製効率 を高めることができる゙)。この戦略にしたがった油脂関 連化合物の精製を以下に述べる。

\section{$3 \cdot 1$ 高度不飽和脂肪酸（PUFA）の精製}

$2 \cdot 1 \cdot 1$ 項で述べたように, PUFA 含有油の選択的加水 分解を繰り返しても未分解アシルグリセロール中の PUFA 含量を $70 \%$ 以上に高めることはできない3)。これ は, 酵素の持つ脂肪酸特異性に起因し, 反応条件を工夫 して脂肪酸特異性をより厳密にすることができれば目的 脂肪酸の更なる高純度化が可能となる。以下に選択的工 
ステル化と選択的アルコリシスを利用したPUFAの高 純度精製について述べる。

\section{$3 \cdot 1 \cdot 1$ 選択的エステル化を利用した PUFA の精製}

PUFA 含有油脂を加水分解するとPUFA を含んだ FFA 混合物を調製することができる。この非選択的加 水分解には, PUFA も比較的良く認識するPseudomonas 属, Burkholderia 属, Alcaligenes 属などの リパーゼが効果的である。加水分解反応後, 蒸留やへキ サン抽出法を採用することにより反応液から FFA を回 収することができる。

得られた FFA 混合物にラウリルアルコール $(\mathrm{LauOH})$ を加え, 目的とする PUFA を認識しにくい酵素 $(C$. rugosa, R. oryzae リパーゼなど）でエステル化すると, 目的 PUFA 以外の脂肪酸はラウリルエステル（FALE） に変換され, 目的 PUFA を未反応の FFA 画分に濃縮す ることができる。反応系中に存在する LauOH, FFA， FALE は, 蒸留法, あるいは蒸留法とへキサン抽出法と の組み合わせにより分画することができる。なお， 1 回 の選択的エステル化で PUFA の純度を目標值まで上げ ることができなければ，エステル化を繰り返すとよ ( ${ }^{21)}$ 。このプロセスを採用することにより，DHAを $91 \%{ }^{22)}$, GLA を $99 \%{ }^{23)}$, AA を $97 \%{ }^{24)}$, ジホモ- $\gamma-$ リ レン酸を $95 \%{ }^{25)}$ まで精製することができる。

なお，この精製戦略は，共役リノール酸異性体 $(9 c$, $11 t-, 10 t, 12 c-)$ の分画にも採用でき, 両異性体の純度 を $96 \%$ 以上に高めることができる ${ }^{26.27) 。 ~}$

\section{$3 \cdot 1 \cdot 2$ 選択的アルコリシスを利用した PUFA の精製}

最初の工程はPUFA 含有油の非選択的エタノリシス である。従来この工程では, アルカリ触媒を用いた化学 法が採用されていた。しかし，化学法はPUFAの異性 化を誘発する危険性があり，またアルカリ廃棄物，アル カリ廃水の処理も課題となっている。これらの問題点は 酵素法を採用することにより解決することができる。し かし, PUFA 含有油のエ夕ノリシスに効果的な固定化 C. antarctica リパーゼは, 反応系中に $\mathrm{EtOH}$ のミセル が存在したとき，このミセルと接触すると容易に失活す る。そこで, PUFA 含有油と EtOH が完全に溶解する反 応条件，すなわち，PUFA 中の全脂肪酸に対して $1 / 3$ モ ル量のエタノールを加えて反応を開始し, 反応の進行と 共に $1 / 3$ モル量のエ夕ノールを 2 回添加する 3 段階逐次 添加法を確立した ${ }^{28)}$ 。この方法によりマグロ油の $95 \%$ 以 上を脂肪酸エチルエステルに変換することができる。

マグロ油由来の脂肪酸エチルエステルを分子蒸留に供 し，57\%の DHA エチルエステル（DHAEE）を含有す る濃縮物を得た。次いで，この FAEEに LauOHを加 え, DHA を認識しにくいリパーゼ（固定化 R. oryzae
あるいはRhizomucor miehei リパーゼ) でアルコリシ スした。その結果，DHA 以外の脂肪酸はラウリルエス テルに変換され，DHA はエチルエステル画分に濃縮さ れた（収率 $52 \%$ ，純度 $90 \%$ ）。反応液から DHAEE を含 むFAEE 画分は蒸留によって容易に回収することがで きる ${ }^{29)}$ 。

\section{$3 \cdot 2$ トコフェロール，ステロールの精製}

植物油を精製する脱臭工程からの副産物に脱臭留出物 がある。この留出物から, 脂肪酸のメチルエステル化 (化学法), イオン交換クロマトグラフィー, 溶媒分画, 分子蒸留などの単位操作を組み合わせたプロセスを経 て，トコフェロールとステロールが精製されている。こ こに酵素法を導入するとトコフェロールとステロールを 高収率，高純度に精製することができる（Fig. 2)。

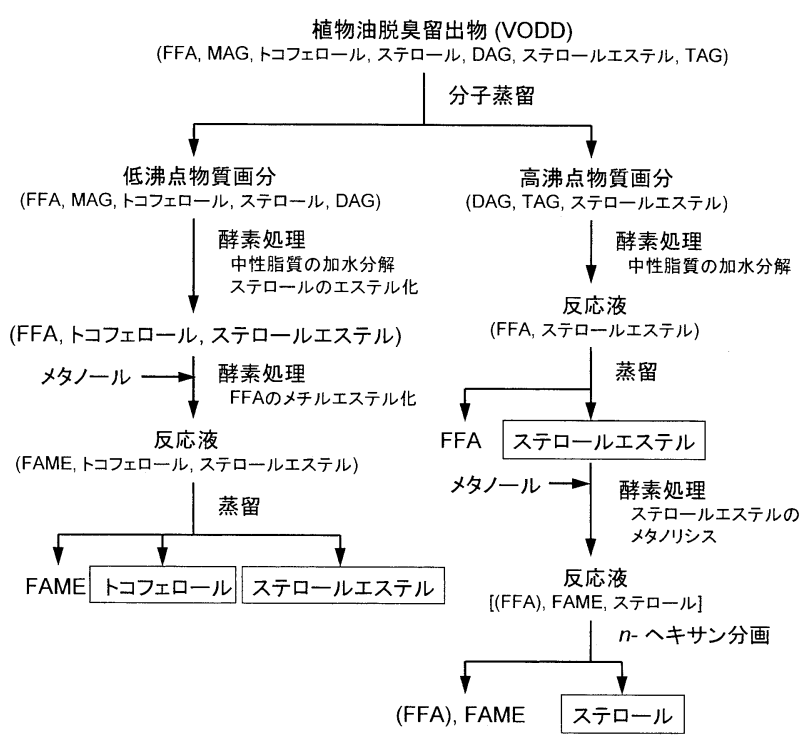

Fig. 2 植物油脱臭留出物からトコフェロールとステロールを 精製するプロセス

まず脱臭留出物を蒸留により低沸点物質画分と高沸点 物質画分に分ける。低沸点物質画分の主成分はFFA, $\mathrm{MAG}, \mathrm{DAG}$, トコフェロール，ステロールで，高沸点 物質画分の主成分は DAG, TAG，ステロールエステル である。まず低沸点物質画分のトコフェロールを収率よ く高純度に精製するために，(1) MAGとDAGを加水分 解してFFA に変換し，（2）ステロールを FFA でエステ ル化してステロールエステルに変換し，（3）FFAをメチ ルエステル化して FAMEに変換すると，低沸点物質画 分の主成分はFAME，トコフェロール，ステロールエ ステルとなる。これらの化合物の沸点は大きく異なるこ とから分子蒸留により効率よく分画することができる。 この戦略にしたがい，1バッチで 3 つの反応を行う反応 系を構築した。まず，低沸点物質画分に水を $5 \%$ になる ように加え，C. rugosaリパーゼによる処理を開始する。 
MAG, DAGは速やかに加水分解され, ステロールと脂 肪酸のエステル化が始まる。反応開始直後から 20 $\mathrm{mmHg}$ で脱水を始めておくと, ステロールの $95 \%$ 以上 がステロールエステルに変換される。反応が平衡に達し

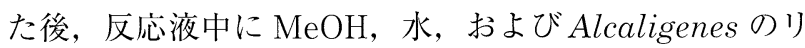
パーゼを添加し，反応を継続すると反応系中の FFAの 95\%以上をFAMEに変換することができた。反応液を 回収して分子蒸留による分画を行った結果，トコフェ ロールは収率 88\%で純度 $72 \%$ まで高めることができ， ステロールはエステル体として収率 97\%で純度 97\%ま で高めることができだ0)。

次は, 高沸点物質画分に存在するステロールエステル の精製である。高沸点物質画分をC. rugosaリパーゼで 処理すると，夾雑物質である中性脂質（TAG, DAG） はほぼ完全に加水分解されたが，ステロールエステルは ほとんど加水分解されない。したがって, 反応後の反応 液中にはFFA とステロールエステルだけが存在し, 両 化合物は蒸留により容易に分画できる。一連の操作によ り，ステロールエステルは収率 88\%で純度を $97 \%$ まで 高めることができた ${ }^{31)}$ 。

以上のプロセスによるとトコフェロールとステロール は収率よく高純度に精製することができる。しかし, 精 製したステロールの分子型はエステル体である。このエ ステル体を遊離体に戻すのに酵素法は非常に効果的であ る。ステロールエステルをリパーゼで加水分解すると， 加水分解率は $20 \sim 50 \%$ 程度で効率よく遊離体に変換す ることはできない。これは加水分解とエステル化の可逆 反応により，平衡に達してしまうからであると予想され た。そこで, 加水分解の反応産物である FFA をメチル エステルに変換し, 反応の平衡をステロールエステルの 分解に傾ける工夫をした。すなわち，ステロールエステ ル, 水, P. aeruginosaリパーゼからなる加水分解の反 応系に $\mathrm{MeOH}$ を添加した反応を行った。その結果, 加 水分解によって生成したFFA FFA とステロールのエステル化を抑えることができた。 この反応系を利用すると, ステロールエステルの遊離体 への変換率は $98 \%$ に達し, 反応液からの遊離ステロー ルの精製にはへキサン分画が効果的である（収率 $92 \% ，$ 純度 $99 \%)^{32)}$ 。

\section{4 酵素法によるバイオディーゼル燃料の製造}

FAME はバイオディーゼル然料（BDF）と呼ばれ， ディーゼルエンジンからの排ガスは軽油由来の排ガスよ りクリーンである。加えて, BDF は再生可能な然料で あることからヨーロッパでは菜種油から生産されてお り, 最近では東南アジアでパーム油からの生産が増えて
いる。現在，BDFはアルカリ触媒を用いた油（TAG） のメタノリシスにより製造されている。この化学法は, 簡単で安価な製造方法であるが，グリセリンを含んだア ルカリ性廃裹物の処理, アルカリ廃水の処理などの課題 を抱えている。この問題を解決する方法の一つとして酵 素法が提案されている。

\section{$4 \cdot 1$ 廃食用油から BDF の製造}

油（TAG）をFAMEに変換するとき少なくとも全脂 肪酸に対して等モル量（理論量という）の $\mathrm{MeOH}$ が必 要である。一方, TAG に対する $\mathrm{MeOH}$ の溶解度は理論 量の約 $1 / 2$ であり，理論量の $\mathrm{MeOH}$ を TAG に加えると $\mathrm{MeOH}$ の一部はミセルとして存在する。一般に酵素は短 鎖アルコール（MeOH や EtOH）に対して不安定であ り，ミセル状の $\mathrm{MeOH}$ と接触すると失活してしまう。 しかし, MeOH がTAG中に完全に溶解している状態で 反応を行うと，この失活は回避できる ${ }^{33)}$ 。

TAGをメタノリシスして FAMEを製造するとき, 固 定化 C. antarctica リパーゼが効果的である。油に理論 量の $1 / 3$ 量の $\mathrm{MeOH}$ と固定化酵素を加えて反応を開始 し, $\mathrm{MeOH}$ が消費されてから 1/3 量の $\mathrm{MeOH}$ を 2 回添 加する 3 段階逐次添加法を採用すると, FAME 含量は 97\%以上に達する。この反応系で，酵素の失活はほとん ど認められず，長期間（少なくとも 100 日以上）使用す ることができる ${ }^{33)}$ っこのプロセスを採用すると廃食用油 でも FAMEに変換することができる。ただし，廃食用 油は脂肪酸の酸化物や重合物を含んでいることから， FAMEへの変換率は精製植物油を原料としたときの変 換率に比べるとわずかながら低くなる ${ }^{34)} 。$

\section{$4 \cdot 2$ ダーク油から BDF の製造}

植物油を精製する際の脱酸工程からアルカリ油㳯が副 成されてくる。このアルカリ油滓を中和して回収した油 分は黒褐色を呈していることからダーク油と呼ばれてい る。また，この油分はFFA とアシルグリセロールで構 成されていることから acid oil とも呼ばれている。この ダーク油に $\mathrm{MeOH}$ を加え, $4 \cdot 1$ 項で述べた固定化 $C$. antarctica リパーゼで処理すると，ダーク油中の FFA の $98 \%$ 以上がFAME に変換される ${ }^{35,36)}$ 。しかし，この メチルエステル化によって生じた水がアシルグリセロー ルのメタノリシスを完全に抑えてしまう。そこでまず, ダーク油中の FFA F FAMEに変換した後, 反応系中 の水を減圧下で除去する。次いで, 得られた脱水反応液 中のアシルグリセロールをメタノリシスして FAMEに 変換する 2 段階反応が構築された。なお，ダーク油中に は酵素反応を阻害する化合物が含まれており（未同定）， 第 1 工程のメチルエステル化では $\mathrm{MeOH}$ を加えること により，第 2 工程のメタノリシスでは油（TAG）を添 
加することにより酵素の阻害は解除された。また第 2 工 程では，グリセリンの添加により酵素は著しく安定化 し，固定化酵素は長期間（少なくとも100日以上）使用 することができた ${ }^{36)}$ 。

\section{5 おわりに}

今人類に課せられた大きな課題の一つは，環境に配慮 した製造プロセスを構築し，持続可能な社会を構築して いくことである。この中にあって, 省エネルギー, 廃棄 物の低減化, 環境にやさしいといった観点から生物反応 は注目されている技術の一つである。しかし化学反応に 比べて生物反応は時間がかかり，コストがかかりすぎる という問題点もある。この生物反応の欠点を補い，実生 産プロセスとしての採用に到るには，生物反応の持つ最 大の特徵, すなわち化学触媒では達成できない厳密な基 質特異性を最大限に利用しなければならない。本稿で は，リパーゼの基質特異性と触媒する反応をうまく組み 合わせたプロセスを開発することにより，化学反応では 困難な機能性油脂が製造でき，また油糧資源から效率よ く有用物質が精製できることを紹介してきた。また，未 利用バイオマスの再資源化にも生物反応が利用できる可 能性を示す例として，酵素法による未利用油糧資源の $\mathrm{BDF} へ$ 変換についても述べてきた。今後のものづく り産業界では, 生物反応や化学反応の利点を組み合わせ た複合プロセスの構築に向け，今まで以上の取り組みが 求められるようになると予想される。このような状況の 下で，本稿で述べたリパーゼ反応の利点が皆様の頭の片 隅に残ることを願い結語とする。

\section{文献}

1）永尾寿浩，島田裕司，杉原耿雄ら，大阪市立工業研究 所報告，第 117 回 (2001)。

2）渡辺嘉, 永尾寿浩, 小林敬ら, 大阪市立工業研究 所報告，第 129 回 (2006).

3) Y. Shimada, T. Nagao \& Y. Watanabe, Handbook of Industrial Biocatalyis, (C.T. Hou edn.), CRC Press, Boca Raton, p.8-1 8-27 (2005).

4) S. Negishi, S. Shirasawa, Y. Arai et al., Enz. Microb. Technol., 32, 66-70 (2003).

5）島田裕司, 食品酵素化学の最新技術と応用ーフードプロ テオミクスへの展望一，(井上國世監修)，シーエム シー出版，東京，p.172-183 (2004).

6) Y. Shimada, A. Sugihara, H. Nakano et al., J. Ferment. Bioeng., 83, 321-7 (1997).

7) R. Irimescu, K. Furihata, K. Hata et al., J. Am. Oil Chem. Soc., 78, 285-9 (2001).

8) Y. Shimada, Y. Watanabe, A. Sugihara et al., J. Mol. Catal. B: Enzym., 17, 133-42 (2002).

9) R: Irimescu, K. Furihata, K. Hata et al., J. Am. Oil Chem. Soc., 78, 743-8 (2001).
10) A. Kawashima, Y. Shimada, T. Nagao et al., J. Am oil Chem. Soc., 79, 871-7 (2002).

11) T. Nagao, A. Kawashima, M. Sumida et al., J. Am oil Chem. Soc., 80, 867-72 (2003).

12）島田裕司，食品工業に扔ける科学・技術の進歩，（日本 食品科学工学会編), 光琳, 東京, p.121-43 (2003).

13) Y. Shimada, J. Ogawa, Y. Watanabe et al., Lipids, 38, 1281-6 (2003).

14) G.P. McNeil, S. Shimizu \& T. Yamane, J. Am oil Chem. Soc., 68, 1-5 (1991).

15) Y. Watanabe, Y. Shimada, Y. Yamauchi-Sato et al., J. Am oil Chem. Soc., 79, 891-6 (2002).

16) P. Pinsirodom, Y. Watanabe, T. Nagao et al., J. Am oil Chem. Soc., 81, 543-7 (2004).

17) S. Yamaguchi \& T. Mase, J. Ferment. Bioeng., 72, 162-7 (1991).

18) Y. Watanabe, Y. Yamauchi-Sato, T. Nagao et al., J. Am oil Chem. Soc., 80, 909-14 (2003).

19) Y. Watanabe, Y. Yamauchi-Sato, T. Nagao et al., J. Mol. Catal. B: Enzym., 27, 249-54 (2004).

20) Y. Watanabe, Y. Yamauchi-Sato, T. Nagao et al., J. Am. Oil Chem. Soc., 82, 619-23 (2005).

21) Y. Shimada, T. Nagao \& Y. Watanabe, Nutraceutical and Specialty Lipids and their Co-Products, (F. Shahidi edn.) CRC Press, Boca Raton, p.365-86 (2006).

22) Y. Shimada, K. Maruyama, A. Sugihara et al., J. Am. Oil Chem. Soc., 74, 1441-6 (1997).

23) Y. Shimada, N. Sakai, A. Sugihara et al., J. Am. Oil Chem. Soc., 75, 1539-44 (1998).

24) A. Yamauchi, T. Nagao., Y. Watanabe et al., J. Am. Oil Chem. Soc., 82, 833-7 (2005).

25) T. Nagao, Y. Watanabe, T. Kobayashi et al., J. Mol. Catal. B: Enzym., 44, 14-9 (2007).

26) T. Nagao, Y. Shimada, Y. Yamauchi-Sato et al., J. Am. Oil Chem. Soc., 79, 303-8 (2002).

27) Y. Shimada, T. Nagao \& T. Kobayashi, Biocatalysis and Biotechnology for Functional Foods and Industrial Products (C.T. Hou \& J.F. Shaw edn.), CRC Press, Boca Raton, p.23-35 (2007).

28) Y. Watanabe, Y. Shimada, A. Sugihara et al., J. Biosci. Bioeng., 88, 622-6 (1999).

29) K. Maruyama, Y. Shimada, T. Baba et al., J. Jpn. Oil Chem. Soc., 49, 793-9 (2000).

30) T. Nagao, T. Kobayashi, Y. Hirota et al., J. Mol. Catal. B: Enzym., 37, 56-62 (2005).

31) Y. Hirota, T. Nagao, Y. Watanabe et al., J. Am. Oil Chem. Soc., 80, 341-6 (2003).

32) Y. Shimada, T. Nagao, Y. Watanabe et al., J. Am. Oil Chem. Soc., 80, 243-7 (2003).

33) Y. Shimada, Y. Watanabe, T. Samukawa et al., J. Am. Oil Chem. Soc., 76, 789-93 (1999).

34) Y. Watanabe, Y. Shimada, A. Sugihara et al., J. Am. Oil Chem. Soc., 78, 703-7 (2001).

35) Y. Watanabe, P. Pinsirodom, T. Nagao et al., J. Am. Oil Chem. Soc., 82, 825-31 (2005).

36) Y. Watanabe, Y. Shimada, A. Sugihara et al., J. Mol. Catal. B: Enzym., 44, 99-105 (2007). 